\title{
Front Matter: Volume 6845
}

, "Front Matter: Volume 6845," Proc. SPIE 6845, Optical Methods for Tumor Treatment and Detection: Mechanisms and Techniques in Photodynamic Therapy XVII, 684501 (28 February 2008); doi: 10.1117/12.792103 


\section{Optical Methods for Tumor Treatment and Detection: Mechanisms and Techniques in Photodynamic Therapy XVII}

David Kessel

Editor

19-20 January 2008

San Jose, California, USA

Sponsored and Published by

SPIE 
The papers included in this volume were part of the technical conference cited on the cover and title page. Papers were selected and subject to review by the editors and conference program committee. Some conference presentations may not be available for publication. The papers published in these proceedings reflect the work and thoughts of the authors and are published herein as submitted. The publisher is not responsible for the validity of the information or for any outcomes resulting from reliance thereon.

Please use the following format to cite material from this book:

Author(s), "Title of Paper," in Optical Methods for Tumor Treatment and Detection: Mechanisms and Techniques in Photodynamic Therapy XVII, edited by David Kessel, Proceedings of SPIE Vol. 6845 (SPIE, Bellingham, WA, 2008) Article CID Number.

ISSN 1605-7422

ISBN 9780819470201

Published by

SPIE

P.O. Box 10, Bellingham, Washington 98227-0010 USA

Telephone +1 3606763290 (Pacific Time) · Fax +1 3606471445

SPIE.org

Copyright (C) 2008, Society of Photo-Optical Instrumentation Engineers.

Copying of material in this book for internal or personal use, or for the internal or personal use of specific clients, beyond the fair use provisions granted by the U.S. Copyright Law is authorized by SPIE subject to payment of copying fees. The Transactional Reporting Service base fee for this volume is $\$ 18.00$ per article (or portion thereof), which should be paid directly to the Copyright Clearance Center (CCC), 222 Rosewood Drive, Danvers, MA 01923. Payment may also be made electronically through CCC Online at copyright.com. Other copying for republication, resale, advertising or promotion, or any form of systematic or multiple reproduction of any material in this book is prohibited except with permission in writing from the publisher. The CCC fee code is 1605 $7422 / 08 / \$ 18.00$.

Printed in the United States of America.

Publication of record for individual papers is online in the SPIE Digital Library.

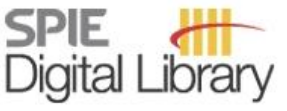

SPIEDigitallibrary.org

Paper Numbering: Proceedings of SPIE follow an e-First publication model, with papers published first online and then in print and on CD-ROM. Papers are published as they are submitted and meet publication criteria. A unique, consistent, permanent citation identifier (CID) number is assigned to each article at the time of the first publication. Utilization of CIDs allows articles to be fully citable as soon they are published online, and connects the same identifier to all online, print, and electronic versions of the publication. SPIE uses a six-digit CID article numbering system in which:

- The first four digits correspond to the SPIE volume number.

- The last two digits indicate publication order within the volume using a Base 36 numbering system employing both numerals and letters. These two-number sets start with $00,01,02,03,04$, 05, 06, 07, 08, 09, 0A, OB ... 0Z, followed by 10-1Z, 20-2Z, etc.

The CID number appears on each page of the manuscript. The complete citation is used on the first page, and an abbreviated version on subsequent pages. Numbers in the index correspond to the last two digits of the six-digit CID number. 


\section{Contents}

vii Conference Committee

\section{SESSION 1 PRECLINICAL I}

684502 Promotion of PDT efficacy by HA14-1 (Invited Paper) [6845-01]

D. Kessel, M. Price, K. Haagenson, Wayne State Univ. (USA)

\section{SESSION 2 PRECLINICAL II}

684505 Lysosome vs. mitochondrion as photosensitizer binding site: how does the tortoise overtake the hare? (Invited Paper) [6845-04]

N. L. Oleinick, K. Azizuddin, S. Chiu, S. Joseph, M. E. Rodriguez, L. Xue, P. Zhang,

M. E. Kenney, M. Lam, Case Western Reserve Univ. (USA); A.-L. Nieminen, Medical Univ. of South Carolina (USA)

684506 Contribution of mitochondria and lysosomes to photodynamic therapy-induced death in cancer cells [6845-05]

A.-L. Nieminen, Medical Univ. of South Carolina (USA); K. Azizuddin, P. Zhang, M. E. Kenney, Case Western Reserve Univ. (USA); P. Pediaditakis, Univ. of North Carolina, Chapel Hill (USA); J. J. Lemasters, Medical Univ. of South Carolina (USA); N. L. Oleinick, Case Western Reserve Univ. (USA)

684507 Protein oxidation by the phthalocyanine photosensitizer Pc 4 and light: detection of a unique singlet oxygen-generated product in cytochrome $c$ [6845-06]

M. E. Rodriguez, J. Kim, M. E. Kenney, N. L. Oleinick, V. E. Anderson, Case Western Reserve Univ. (USA)

\section{SESSION 3 DOSIMETRY}

$68450 \mathrm{C}$ Interstitial diffuse optical tomography using an adjoint model with linear sources [6845-11] X. Zhou, T. C. Zhu, Univ. of Pennsylvania (USA)

\section{SESSION 4 PRECLINICAL III}

6845 OD Noninvasive murine glioma detection improved following photobleaching of skin PpIX fluorescence [6845-12]

S. L. Gibbs-Strauss, S. C. Davis, J. A. O'Hara, P. J. Hoopes, Dartmouth College (USA);

T. Hasan, Wellman Ctr. for Photomedicine, Massachusetts General Hospital (USA);

B. W. Pogue, Dartmouth College (USA) and Wellman Ctr. for Photomedicine, Massachusetts General Hospital (USA) 


\section{SESSION $5 \quad$ CLINICAL STUDIES}

6845 0J Preliminary study of transurethral photodynamic therapy mediated with Tookad in a canine prostate model [6845-18]

Z. Huang, F. W. Hetzel, Q. Chen, K. C. Dole, Univ. of Colorado, Denver (USA)

\section{SESSION 6 DELIVERY/TOMOGRAPHY}

684500 Linear feasibility algorithms for treatment planning in interstitial photodynamic therapy [6845-23]

A. Rendon, Univ. of Toronto (Canada) and Univ. Health Network (Canada); J. C. Beck, Univ. of Toronto (Canada); L. Lilge, Univ. of Toronto (Canada) and Univ. Health Network (Canada)

6845 OP Sensitivity analysis of imaging geometries for prostate diffuse optical tomography [6845-24] X. Zhou, T. C. Zhu, Univ. of Pennsylvania (USA)

$6845 \mathrm{OQ}$ Integrated light dosimetry system for prostate photodynamic therapy [6845-25]

J. Li, T. C. Zhu, X. Zhou, D. Andreea, J. C. Finlay, Univ. of Pennsylvania (USA)

\section{SESSION 7 NEW SENSITIZERS}

6845 OS Synthesis, characterization, and two-photon PDT efficacy studies of triads incorporating tumor targeting and imaging components [6845-27]

C. W. Spangler, Rasiris, Inc. (USA); J. Starkey, A. Rebane, M. Drobizhev, Montana State Univ., Bozeman (USA); F. Meng, A. Gong, MPA Technologies, Inc. (USA)

6845 OT Time-resolved luminescence measurements of the magnetic field effect on paramagnetic photosensitizers in photodynamic reactions [6845-28]

O. Mermut, INO, Biophotonics (Canada) and McMaster Univ. (Canada); J.-P. Bouchard, J.-F. Cormier, P. Desroches, INO, Biophotonics (Canada); K. R. Diamond, McMaster Univ. (Canada); M. Fortin, P. Gallant, S. Leclair, INO, Biophotonics (Canada); J.-S. Marois, Univ. Laval (Canada); I. Noiseux, INO, Biophotonics (Canada); J.-F. Morin, Univ. Laval (Canada); M. S. Patterson, McMaster Univ. (Canada); M. Vernon, INO, Biophotonics (Canada)

6845 OU Histopathological and expression profiling studies of early tumor responses to near-infrared PDT treatment in SCID mice [6845-29]

J. R. Starkey, A. Rebane, M. A. Drobizhev, Montana State Univ. (USA); F. Meng, A. Gong, MPA Technologies, Inc. (USA); A. Elliott, K. Mclnnerney, E. Pascucci, Montana State Univ. (USA); C. W. spangler, MPA Technologies, Inc. (USA)

\section{POSTER SESSION}

6845 0X Photodynamic therapy (PDT) to treat a chronic skin wound in a dog [6845-32]

R. Hage, H. Plapler, R. A. Bitar, Univ. Federal de São Paulo (Brazil)

$6845 \mathrm{OY}$ The role of autofluorescence diagnostics in the diseases of oral mucosa [6845-34]

A. Kosciarz-Grzesiok, J. Waskowska, A. Kawczyk-Krupka, A. Ledwon, A. Misiak, W. Latos,

R. Koszowski, K. Sieron-Stoltny, A. Sieron, Medical Univ. of Silesia (Poland) 
684510 The difference of the PDT's effects between interstitial lighting and continuous lighting in low oxygen density [6845-36]

J. Yang, Tianjin Medical Univ. (China) and Tianjin Univ. (China); Y. Li, Tianjin Medical Univ. (China); T. Liu, T. Xu, Tianjin Univ. (China)

684512 In silico analysis of quantifying tumor hemoglobin saturation using the optical pharmacokinetic system (OPS) [6845-38]

S. C. Kanick, R. S. Parker, Univ. of Pittsburgh (USA)

684517 Fluorescence quantum yield of verteporfin is independent of oxygen [6845-43]

T. Monahan, S. Jiang, Dartmouth College (USA); B. Pogue, Dartmouth College (USA) and Wellman Ctr. for Photomedicine, Massachusetts General Hospital (USA)

684519 Dosimetric considerations of interstitial photodynamic therapy of the canine prostate mediated by intra-arterially administered hypocrellin derivative [6845-45]

W. Liu, D. J. Dickey, Univ. of Alberta (Canada); Z. Xiao, R. B. Moore, Cross Cancer Institute (Canada); J. Tulip, Univ. of Alberta (Canada)

Author Index 
Downloaded From: https://www.spiedigitallibrary.org/conference-proceedings-of-spie on 26 Apr 2023

Terms of Use: https://www.spiedigitallibrary.org/terms-of-use 


\title{
Conference Committee
}

\author{
Symposium Chairs \\ James Fujimoto, Massachusetts Institute of Technology (USA) \\ R. Rox Anderson, Wellman Center for Photomedicine, Massachusetts \\ General Hospital (USA) and Harvard School of Medicine (USA)
}

Program Track Chair

Reza S. Malek, Mayo Clinic (USA)

Conference Chair

David Kessel, Wayne State University (USA)

Conference Cochair

Tayyaba Hasan, Wellman Center for Photomedicine, Massachusetts General Hospital (USA) and Harvard Medical School (USA)

Program Committee

Thomas H. Foster, University of Rochester (USA)

Charles J. Gomer, Childrens Hospital Los Angeles (USA)

Nancy L. Oleinick, Case Western Reserve University (USA)

Brian W. Pogue, Dartmouth College (USA), Wellman Center for Photomedicine, Massachusetts General Hospital (USA), and Harvard Medical School (USA)

Kevin M. Smith, Louisiana State University (USA)

Kenneth K. Wang, Mayo Clinic (USA)

\section{Session Chairs}

1 Preclinical I

David Kessel, Wayne State University (USA)

2 Preclinical II

Charles J. Gomer, Childrens Hospital Los Angeles (USA)

3 Dosimetry

Tayyaba Hasan, Wellman Center for Photomedicine, Massachusetts General Hospital (USA) and Harvard Medical School (USA) 
4 Preclinical III

Thomas H. Foster, University of Rochester (USA)

$5 \quad$ Clinical Studies

Kenneth K. Wang, Mayo Clinic (USA)

6 PDT Delivery

Brian W. Pogue, Dartmouth College (USA), Wellman Center for Photomedicine, Massachusetts General Hospital (USA), and Harvard Medical School (USA)

7 Delivery/Tomography

Soumya Mitra, University of Rochester (USA)

8 New Sensitizers

Timothy C. Zhu, University of Pennsylvania (USA)

Poster Session

David Kessel, Wayne State University (USA) 